RJPSS March 2020 Vol. XLV No.1, ISSN: (P)0258-1701 (e)2454-3403 Impact Factor: 7.712

\title{
Visionary Perception of Swami Vivekanandand Rabindranath Tagore Towards Education
}

\author{
Dr. Indu Sharma \\ Asso. Prof., Deptt. of Political Science, \\ D.A.V. PG College, Bulandshahr (U.P.) \\ Email:drindusharma77@gmail.com
}

\begin{abstract}
The educationist's views on education reveal that they were the outstanding product of Indian nationalism and s brilliant exponents of ancient Indian wisdom. There is a galaxy of Indian intellectuals who did experiments with education on Indian soil like Swami DayanandSarswati, MahamanaMadanmohanMalviya, Mahatma Gandhi, Dr. Zakir Hussain, Swami Vivekanand, RabindraNath Tagore, MohammdIqbal, Dr. Radhakrishnan, MaulaAbulKalm Azad, Sir Syyad Ahmad Khan,ShriAurobindo and others. The researcher regardsall these philosophers with respect and gratitude as they enriched the Indian education system with their intellectualism as well as vision of unit in diversity. In fact, these people were responsible for the 'Indian Renaissance' in the education system. Due to their selfless hard work and participation, Indian planners set fourth an indigenous education system since independence. Compared today educational level of Indians at the time of independence, today India has produced hundred times graduates, post graduates, engineers, doctors, lawyers, scientists and research scholars, however the population has just tripled.

Here this paper express the educational views and aims of education of Swami Vivekanandand RabindraNath Tagore the following passages for our understanding of problems and prospects of Indian education with historical antecedents.

Key Words-Education, Philosophers, Independence, Intellectuals, Education System, Philosophy and Visionary Perception, Cultural heritage.
\end{abstract}

Reference to this paper should be made as follows:

Received: 16.12.2019

Approved: 05.03.2020

Dr. Indu Sharma,

Visionary Perception of Swami Vivekanandand Rabindranath Tagore

Towards Education

Article No. 01

RJPSS March 2020, Vol. XLV No. 1, pp. 001-007

Online available at: https://anubooks.com/ ?page $\mathrm{id}=6389$

https://doi.org/10.31995/

rjpss.2020.v45i01.001 
Visionary Perception of Swami Vivekanandand Rabindranath Tagore Towards Education Dr. Indu Sharma

\section{Introduction}

Educationin itselfis a very significant variable for investigation. Unfortunately it has not received due attention of the national community. Education is a creative process. Education is the process of facilitating learning, or the acquisition of knowledge, skills values and habits. Education can take place in formal or informal settings and any experience that have a formative effect on the way one thinks, feels or acts may be considered education. The view of both of philosophers on education reveals that they were one of the most and distinguished educationists of our country. Even though they were sufficiently influenced by the culture and philosophy of the Indian culture and heritage, the contributions of these two philosophers to educational thought and practice are stupendous and magnanimous which form the basis of our study.

The educational contributions of these two philosophers have some commonalities and contrasts in respect of concept of education, aims of education, curriculum, methods and principles of teaching, discipline, role of the teacher, Indianization of education. An attempt has been made to explain all these aspects clearly and cogently as possible.

Swami Vivekananda alias NarendraNathDutta was born in 1863 in Calcutta. He possessed a keen intelligence. When he was five years of age, he was sent to a school. He belonged to a traditional Bengali kayasth family and was one of the nine siblings. The progressive rational approach of his father and the religious temperament of his mother helped shape his thinking and personality. At college he was adept in boxing, riding, swimming and wresling. There he studied History, literature as well as Indian philosophical traditions. He also studied in details the western literature and philosophy. So he was an ardent student of languages, philosophy and poetry. Herbert Spencer and John Stuart Mill were his favourite philosophers and Wordsworth was his favourite poet.

There is lot to learn from Vivekananda's vews on education. He puts lot of emphasis on moral education, religious education, women education etc. Vivekananda's unique contribution to the creation of view India was to open the minds of Indians to their duty to the downtrodden masses. He was the first religious leader in India to speak for the masses, formulate a definite philosophy of service and organize large scale social services.

RabindraNath Tagore was born on 6 May, 1861 in Calcutta. He began to compose verses when he was only eight year old. He had his education mostly at home through private readings. The world recognized the merit of Tagore by awarding 
him the Nobel Prize for literature in 1913 on the English version of his Gitanjali. Tagore was a philosopher, poet, novelist, dramatist, actor, composer, painter and educationist. He was a supporter of humanism. Love of man is the very heart of his religion. Man the divine is the measure of all things for him. He also wrote the short story, 'Bhikharini' in 1877 and the poem collection, SandhyaSangit' in 1882. He drew aspiration by reading the classical poetry of Kalidas and started coming up with classical poems of his own.

In his opinion education is reformatory and expensive process which seeks to unfold all that is good and noble to individual. True knowledge brings enlighten and self-realization. Tagore conceived education as dynamic, living and closely associates with life.

\section{Educational Views}

\section{Educational Views of Swami Vivekananda-}

Swami Vivekananda ranks among the greatest educationists of India. Let researcherelaborates his views on his philosophy of education. According to Vivekanada only study of books is not education. Knowledge lies hidden in the mind of man. He uncovers and develops it by his own efforts. He said that concentration is the key to all knowledge for this, practice of Brahmcharya is essential. Purity of though, speech and deed is self discipline. Education should develop the child physically, mentally and spiritually. He said that boys and girls should receive the same education. Provision for technical education should be made so that industrial growth leads to the economic prosperity of the nation.

Vivekanada said that there should intimate teacher-students relationship. Mass education scheme should be formulated and launched. All those subjects should be included in the curriculum which promotes the material and spiritual advancement of a child. He stressed the need for physical education in curriculum. He appreciated the greatness of Sanskrit. He said that it is the source of all Indian Languages and respiratory of all inhereited knowledge. Therefore, without Sanskrit, it will be impossible to understand Indian Culture. It is like a store house of ancient heritage. To develop our society it is necessary that men and women know this language, besides the knowledge of their mother tongue.

Vivekananda said that Religion is like rice and everything else, is like the curries. He considered Gita, Upanishads and the Vedas as the most important curriculum for religious education. He said that the true religion cannot be limited to a particular place of time. He pleaded for unity of world religion. The truth is the power and untruth is weakness. Knowledge is truth and ignorance is untruth. Thus 
Visionary Perception of Swami Vivekanandand Rabindranath Tagore Towards Education

Dr. Indu Sharma

the truth increases the power, courage and energy. It is the source of light. God is always on the side of goodness. The moral and religious education develops the self confidence among the young men and women.

He considered that unless Indian women secure a respectable place in this country, the nation can never move forward. He insists that the men and women are equally component not only in the academic matters, but also in other spheres of life. His views towards women that, 'the ideal women in India is the mother, the mother first, and the mother last.'

\section{Educational Views of RabindraNath Tagore}

Tagore thinks that the child has an endless thirst for leading his life. He vehemently criticizes the current schools, which snatch away children from the natural surroundings and rear them up in an atmosphere which is full of artificialities and sophistications of the civilized society. The individuality of the child is totally ignored in these schools which try to produce uniform individuals as a machine produces uniform pins.

The concept of his VishvaBharti is in accordance with his notion of greater India. Where the humanity will strive to reach a reconciliation of different races with different religious and civilization. Tagore's VishvBharti is a symbol of his passionate faith in the brotherhood of nations. He put emphasis on 'naturalism' for framing educational model. In education, freedom is the basic guiding force for inculcating interest within a student who will derive inspiration from nature to peruse any branch of knowledge he likes. The establishment of Shantiniketan fulfilled the desired goal of Tagore in the educational front.

\section{Aims of Education-}

\section{Swami Vivekananda and His Aims of Education-}

The prime aim of education is to achieve fullness or perfection already present in a child. The second aim of the education is the physical and mental development of the child of study who may promote national growth and advancement as a fearless and physically well developed citizen of tomorrow.

According to Swami ji character development is a very important aim of any education. For this he emphasized the practice of brahmcharya which fosters development of mental, moral and spiritual powers leading to purity of thoughts, words and deeds. The true aim of education is to develop insight into the individuals so that they are able to search out and realize unity in diversity. Swami Vivekananda has further asserted that physical and spiritual worlds are one, their distinctness is an illusion. Education should develop this sense which unity is diversity. He advocated 
that religious development is an essential aim of education. Thus Swami ji in an education system which in calculates the moral, physical and spiritual qualities among the students.

In Vivekanada's philosophy of education are involved the essential characteristics of idealism, naturalism and pragmatism. Like naturalists Swami Vivekananda emphasis that the real education is possible only through nature and natural propensities. Like, idealists, he insists that the chief aim of education is to develop to the full, the moral and spiritual nature of child, the essence of which is already present in him. Like pragmatists he lays great stress on the western education of technology, commerce, industry and science to achieve material prosperity.

\section{RabindraNath Tagore and His Aims of Education}

According to Tagore, the aim of education is self-realization and this realization by every one is the goal of education. It means the realization of the universal soul in one's self. All those actions, which provide a natural sense of satisfaction and contentment, will promote the educative process.

Tagore has three main principles of education and on establishing VishvBharti, he has described them as follows:-

1. To teach different culture of the East, especially those that originated in India or found shelter within share.

2. To establish, "The Institute of Rural Reconstruction" in order to lay the foundation of a happy contented as human life in the villages and lastly.

3. To seek to establish a living relationship between east and west, to promote inter-cultural, and inter-racial amity and understanding, and fulfill the highest mission of the present age the unification of mankind.

The aim of Shantiniketan is to bring back life in its completeness into the villages making them self reliant and self respectful acquainted with the cultural traditions of their own country, and competent to make an efficient use of the modern resources for the improvement of their physical, intellectual and economic condition.

The aim and objectives of the institute, as originally set forth in detail are as follows - to win the friendship and affection of villages and cultivators by a taking a real interest in all that concern their life and welfare. To take the problems of the village and field to the class-room for study and discussion and to the experimental farm for solution. To carry the knowledge and experience gained in the class-room and the experimental farm to the villagers in the endeavor to improve their sanitation and health; to develop their resources and credit, to help them to sell their produce and buy their requirements to the best advantages, to teach them better method of 
Visionary Perception of Swami Vivekanandand Rabindranath Tagore Towards Education

Dr. Indu Sharma

growing crops and vegetables and to keeping live-stock, to encourage them to learn and practice arts and crafts, and to bring home to them the benefits of associated life, mutual aid and common endeavor.

To encourage in the staff and the students of the departments itself a spirit of sincere service and willing sacrifice in the interest of and on terms of comradeship with their poorer, less educated and greatly harassed neighbours in the village. To put the students in the way of acquiring practical experience in cultivation, dairying, Animal husbandry, poultry-keeping, carpentry, smiting, weaving, tanning, practical sanitation work and in the art and spirit of co- operations.

\section{Conclusion}

The fact is that Vivekananda's educational philosophy is a harmonious synthesis of the ancient Indian ideals and modern western beliefs. As a great educationist he revolutionized almost the entire field of education. His educational views were immensely influenced by the eternal truths of Vedanta. He strongly advocated national education on national lines and based on national tradition.

In short, Swami Vivekananda was a great educationist and he was an idealist at heart. First of all he emphasized spiritual developments, then material prosperity, after that safety of life and then solving the problems of fooding and clothing of masses.

Tagore was a great practitioner. He worked out of his ideas and ideals in very constructive way. The fulfillment of all his theories and concepts found expression in various directions. He struggled to implement his social ideals and strove to build up a social structure through education. This is the reason why his education is easily acceptable by human mind. RabindraNath Tagore is immortal in the world by his work today. Through him India has given her message to mankind and his unique achievements in the field of literature, philosophy, education, art and education have won imperil shamble fame for himself and have raised the status of India in the estimation of the world.

In fact both educationists were none but the sons of India who put their sterling efforts to change the very destiny of India. Though they were philosophers, patriots, educationists etc. They possessed the burning desire in them to raise India to her ancient Pomp and glory and to enable her to get rightful place in the family of nations.

\section{References}

1 Agrawal, J.C., (1981), 'Theory and principles of education', Vikas, New Delhi, pp. 196-197. 
RJPSS March 2020 Vol. XLV No.1, ISSN: (P)0258-1701 (e)2454-3403 Impact Factor: 7.712

2 A Compilation. (2015). Vivekananda as the Turning Point; The rise of a new Spiritual Wave. Kolkata: AdvaitaAshrama Publication.

3 Bharathi, S.V. (2011). Educational philosophy of swami Vivekananda. New Delhi: Discovering Publishing House.

4 Bhatia, K. (1992). 'The philosophical and Sociological Foundations of Education'.

5 Rabindranath Tagore, "East and West" from Creative Unity, Rabindranath Tagore Omnibus 1, New Delhi: Rupa\& Co., 2003, P 147.

6 Rangachari, D. (2011). Swami Vivekananda a man with a vision. United Kingdom: Penguin Publication.

7 S.P. Chaube, “Modern Education," Ram Prasad and Sons, Agra, 1980, P.319.

8 Salker, K.R. (1990), 'Rabindranath Tagore His Impact on Indian Education', Delhi; Sterling publishers private Limited.

9 The Complete Works of Swami Vivekanad, Vol.1.

10 Uma Das Gupta, Rabindranath Tagare: A Biography, New Delhi: Oxford University Press, 2004, p 49.

11 Whitehead, A.N., (1966), 'The Aims of Education'. EnestBeon Limited London. 